Ana BATRIĆEVIĆ, PhD*

Institute of Criminological and Sociological Research, Senior Research Fellow

Andrej KUBIČEK, $M A^{* *}$ Institute of Criminological and Sociological Research, Research Assistant
Original Scientific Article

Received: 10 November 2020 Accepted: 26 November 2020

UDK: $316.723: 391.91$

343.261-052

https://doi.org/10.47152/rkkp.58.3.1

\title{
THE ROLE OF TATTOOS IN PRISON COMMUNITY
}

With their roots set deep in the tradition of many different cultures, carrying the mark of social stigma throughout the early ages of modern prison systems development, and finally, becoming fashion accessories inseparable from modern pop culture, tattoos obtain a rather specific meaning if made behind the prison walls. There are several reasons for that: their symbolism, the roles they have inside the prison community, their relation to criminal behaviour, their impact on offender's re-socialization and re-offending as well as the health risks they cause. Having in mind the worldwide presence of this phenomenon and its local manifestations, the authors of this paper analyse its socio-genesis, taxonomy, functions and consequences as well as potential responses aimed at mitigating the negative impacts of prison tattoos on the life, health and reintegration of offenders. lisation

Key Words: tattoos, prisons, prisoners, recidivism, re-socia-

\footnotetext{
* e-mail: a.batricevic@yahoo.com

** e-mail: andrejkubichek@gmail.com
} 


\section{Introduction - Socio-genesis of Prison Tattoos}

The term "tattooing" refers to inscribing one's skin with lasting patterns and designs (Deter-Wolf et al., 2016: 20) by permanently inserting pigment into punctures in the skin with the help of specially designed needles (Radović, Đurđević, 2017:194). The word "tattoo" was used for the first time as a noun and a verb in the $18^{\text {th }}$ century in the diary of captain James Cook, who took its original form "tatu" from the Tahitian and Samoan languages while sailing across Polynesia (Omelchenko, Karpenko, Volkodav, 2019). Although tattoos are sometimes categorized as an exotic and recent phenomenon in Europe, there are well known ancient historic examples of this practice, as well as ethnographic ones which are still present (among Catholics in Bosnia for example) (Truhelka, 1986).

In spite of the fact that the word "tattoo" is relatively new, tattoos are considered the oldest and the most wide-spread form of body modification (Awofeso, 2002: 162). Archaeological and historical findings suggest that that the first tattoos were made around 12000 years ago (Takač, Pilija, 2012: 249). Numerous ancient mummified tattooed human bodies recovered from all over the world confirm that tattooing was practised at every continent apart from Antarctica as an essential element of Indigenous people's cultural fabric (Deter-Wolf et al., 2016) as well as a component of religious rites (Hellard, Aitken, Hocking, 2007: 477). The role of Indigenous tattoos varied, depending on the specific culture and time-frame, including: demonstrating entry into adulthood, reflecting social status, confirming material success, showing lineage and belonging to a group, directing supernatural forces etc. (Deter-Wolf et al., 2016).

In the Judeo-Christian context, Cain, the first murderer was marked by God on his forehead. Although the book of Genesis doesn't specify what exactly was the nature of that marking, visual stigmas have strong ties with criminality in the very foundations of western culture. In some historic frames, social stigma of crime and bodily stigma in the form of tattoo were merged together in the practice of enforced marking of criminals and prisoners. In ancient Greece and Rome, tattooing was applied as a means to mark slaves, deserters and perpetrators of criminal offences (McCarron, 2008: 88). Throughout the early years of modern prison systems, custodial authorities used tattoos to stigmatize and degrade the convicts (Awofeso, 2002: 162). These tattoos were imposed on the offender by the state to signify judgement, ownership, and the impossibility of rehabilitation (McCarron, 2008: 91). During the late $18^{\text {th }}$ century, thieves in France bore a lily with the letter "V" for voleur on their shoulders, and similar practices were applied in the Russian empire (Goscilo, 2012: 209). Moreover, prisoners that were transported by ships from the United Kingdom to Australia were forcibly tattooed 
for the purpose of surveillance and humiliation (Caplan, 2000, in Awofeso, 2002: 162). Compulsory tattooing of prisoners in the Nazi death camps is the most recent and the most infamous case when tattoos were used as measures of codification aimed at treating individuals like numbers that belonged to the state not only in life but in death as well (McCarron, 2008: 96).

As the state was losing legitimate mandate to tattoo the convicted persons, their desire to tattoo themselves was growing. For example, as compulsory tattooing was abolished in the French penal system in the $19^{\text {th }}$ century, voluntary tattooing among prisoners rapidly increased (McCarron, 2008: 81). A similar situation occurred in Australia, where the shift from compulsory imprint of tattoos on prisoners to voluntarily tattooing among prisoners was apparent from the early convict era (Awofeso, 2002: 162). Enforced tattooing of convicts by prison authorities is currently forbidden in the majority of modern prison systems, but prisoners continue tattooing themselves voluntarily and with a lot of enthusiasm in most prisons of the Western world (Awofeso, 2002: 163). Paradoxically, prisoners appropriated and altered marks that were originally invented to shame them.

For the purpose of this paper, the term "prison tattoo" is not limited only to the tattoos voluntarily made by prisoners behind the prison walls, but it includes also the tattoos professionally done outside prison that are "privileged by the narrative gaze within texts set in prison" (McCarron, 2008: 87). Apart from belonging to the persons who are serving or have served the prison sentence, these tattoos share another common feature - their meaning and message can somehow be linked either to the crime committed by or to the punishment imposed on their owners. So, regardless of the actual location and time of their creation, these tattoos have a deep and unique symbolic continuance that surpasses the time and spatial frameworks of any court judgement or penitentiary institution.

For past two decades, the society's perception of tattooing and tattoos has undergone substantial changes (Dey, Das, 2017). Once being linked to non-mainstream groups (Dey, Das, 2017), nowadays tattooing represents a part of popular culture and is rather common among the general population, particularly in developed countries (Hellard, Aitken, Hocking, 2007: 477). From socio-historical perspective, tattoos used to have expressive functions in the past (marking tribal, religious or professional affiliation), while nowadays they tend to have cosmetic use. Still, in some cases they can retain symbolism of group membership even today, and prison tattoos are a clear example (Katsos et. al, 2018: 21). The fact that modern society does not perceive tattoos as the marks of stigma but rather as fashion accessories only emphasizes the distinction between regular, legally made tattoos and prison tattoos as tattoos that have been created under specific conditions, with specific motives and(or) for a specific purpose. Still, the ties between 
tattoos and deviance are still strongly present in some contexts, and the most productive way to understand the origin of this attachment is to analyse the very birthplace of criminological study of this subject - the work of Cezare Lombroso.

\section{The Origins of the Criminology of Tattoos}

Cezare Lombroso hasn't failed to note great importance of tattoos for both prisoners and criminals. In his very introduction to Criminal man, while describing famous case of Italian brigand Vilella, Lombroso counted tattooing among other atavistic features which criminals and "primitive people", as well as primitive animals, have in common: "Enormous jaws, high cheek-bones, prominent superciliary arches, solitary lines in the palms, extreme size of the orbits, handleshaped or sessile ears found in criminals, savages, and apes, insensibility to pain, extremely acute sight, tattooing, excessive idleness, love of orgies, and the irresistible craving for evil for its own sake, the desire not only to extinguish life in the victim, but to mutilate the corpse, tear its flesh, and drink its blood" (Lombroso, 1911 a: 26). As Maurice Parmelee, the author of the introduction to the 1911. English translation of the study Crime, its Causes and Remedies, critically remarked, it is very interesting that tattoos are treated as other bodily traits, even though they are transmitted by social practices, and not by genes (in: Lombroso, 1911 b: 10-11).

Problematic interpretation uses analogy of tattooing practices of criminals (both born and habitual ones), "primitives" and lower classes (workers, soldiers, sailors) as one of the proves of their members' inborn likeliness. "Primitive people", both ancient (Thracians, Pict and Celts) and contemporary (Eskimos, Wuhaiva and Maori) being more or less deprived of clothes, used tattoos as decorations and marks of distinctions and rank, as the classic of criminology claims (Lombroso, 1911 a: 45). Lombroso is careful to note that there are "normal" people who are tattooed as well, but that they make $0.1 \%$ of population, while $9 \%$ of criminals have tattoos, with recidivists, murderers and thieves being the most likely to be tattooed, and forgers and swindler the least (Lombroso, 1911 a: 46).

Analyses of this phenomenon is in line with Lombroso's nowadays unacceptable racial theories, although the facts that he presented in his work are remarkable and prove his keen interest in this subject and impressive effort in gathering relevant data about it. Concretely, he notes that criminal tattoos consist of designs, hieroglyphics and words and puts strong emphasis on the painfulness of the whole process, which is in accordance with his argument that criminals have greater resistance to pain than "normal people" (Lomborso, 1911 a: 45). 
Lombroso also claims that they purposefully choose parts of the body which are the most sensitive to be tattooed (genital area) - the practice which surpasses even the "savages", and which further indicates criminal's indecency (Lombroso, 1911 a: 47), which can be understood as their rejection of accepted norms.

One of the key features of Lombroso's understanding of the nature of criminal tattoos is the deep connection between their symbolic content and psychological traits of born criminals. Namely, he remarked that especially tattoos made in prison are a product of criminals vindictiveness, because they are "full of solemn oaths of vengeance" (Lombroso, 1911 a: 38-39). For prisoners, they serve as eternal reminders of promised revenge to certain individuals outside the prison. Their content may also include other violent messages (daggers), symbols depicting criminal's career or important life events, committed crimes, initials, place of origin, sentimental declarations (Lombroso, 1911 a: 232-233), or signs of belonging to a criminal group (Lombroso, 1911 a: 46-49). Lombroso again sees strong analogy between the last type of tattoos and "primitive" tribal markings.

\section{The Taxonomy of Contemporary Prison Tattoos}

Unlike the tattoos describe in classical criminological literature, contemporary prison tattoos have many different meanings. Despite their variety, a certain taxonomy or classification of the most common types of contemporary prison tattoos can be made, but it should be noted that not all of them are equally present in all prison systems. Wohlrab et al. have established 10 motivational categories for acquiring a body modification, referring to tattoos and body piercing: beautyart-fashion, individuality, personal narrative, physical endurance, group affiliations-commitment, resistance, spiritual-traditional tradition, addiction to tattoos, sexual motivation and no specific (Wohlrab et al., 2007). From forensic point of view, the position of tattoos can be crucial for the identification of persons' identity, and different locations on the body are usually divided into 5 anatomical regions: head, neck, torso, upper and lower limbs (Katsos et. Al, 2018: 23). Concerning visibility of tattoos, human skin can be divided into 4 zones. Zone 1 includes the head, the neck and the hands; zone 2 includes the outside surface of upper arms, forearms and the lower legs; zone 3 includes the torso, shoulders and the thighs, and zone 4 the intimate parts of the body. Each of the listed regions has specific implications and conveys different messages (Katsos et. Al, 2018: 23 ). Concerning their content, there are five types of prison tattoos, depending on their design, message and motive behind their creation: 1) commodified, 2) Nazi, 3) gang, 4) religious and 5) memento mori (McCarron, 2008: 92). 
Commodified prison tattoos (i.e. prison tattoos as commodified or purchased objects) include those tattoos that are used to construct prisoner's body, alongside with body-building (McCarron, 2008: 96). Namely, through marking his body with tattoos, the prisoner actually confronts the institutional marking that, just like mandatory wearing of prison uniforms, denies his individuality (McCarron, 2008: 96). Such approach to prisoners' perception of body-building and tattooing is plausibly depicted in an autobiographic novel "Record Atila" (Dosije Atila), written by a former prisoner Đorđe Vasiljević. When describing the process of body-building under prison conditions, he emphasizes that at that time for him, having a muscular body ornamented with prison-made tattoos represented the confirmation of his own value and the proof that the prison system did not manage to break him (Vasiljević, 2018: 206). He further confesses that he found an inmate who was willing and skilled enough to have him tattooed with a tattoo machine made from a ball pen, electric motor and batteries, using straightened and sharpened springs taken out from lighters as needles and a mixture of melted rubber slipper and shampoo as ink (Vasiljević, 2018: 206). Explaining the tattoo covering his arm and the upper part of his hand, visible even under long sleeves, he says that he deliberately chose a large tattoo that would always stand out and that could never be

Photograph 1. Correctional Institution in Sremska Mitrovica, 2019.

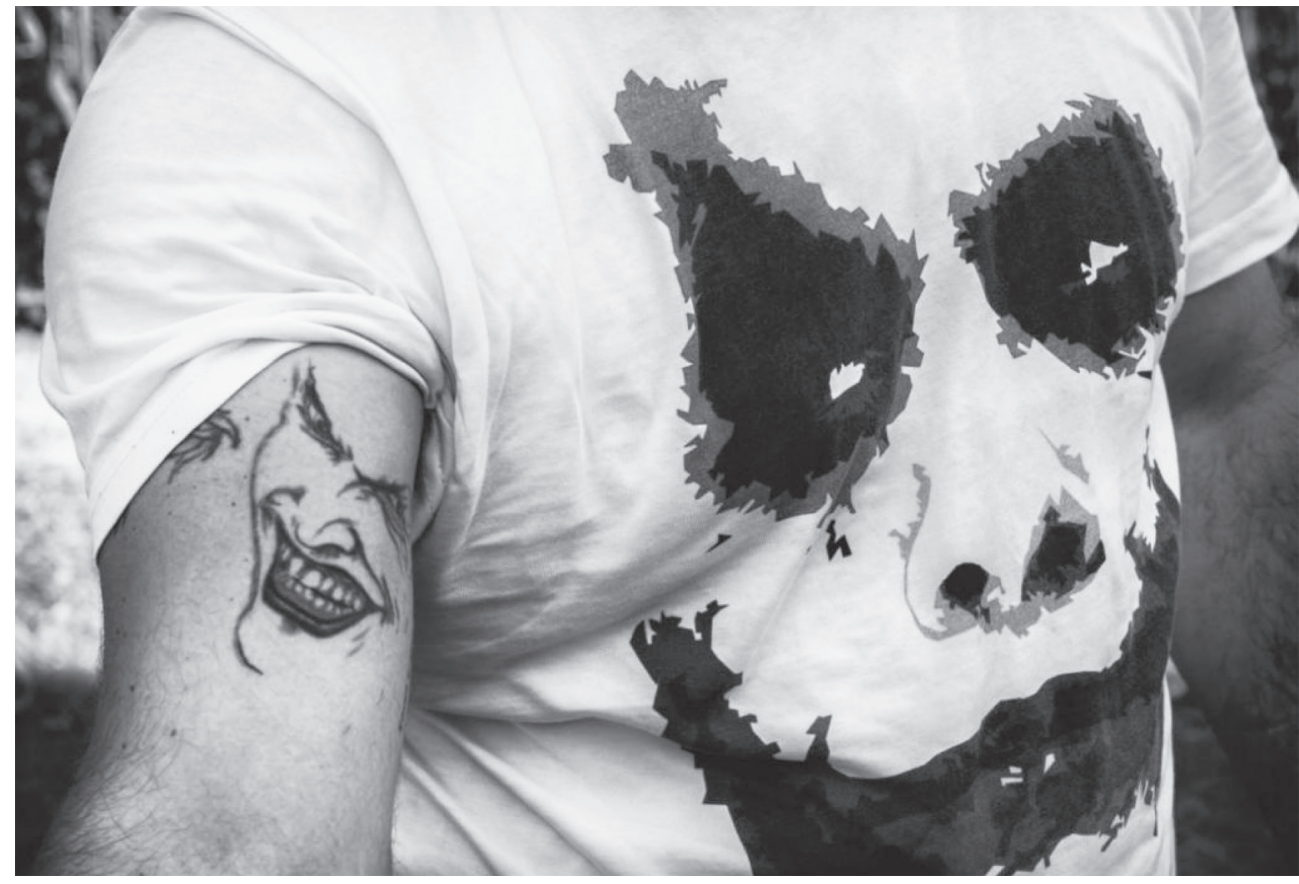

Author: Ana Batrićević 
fully covered with clothes because he wanted some kind of a reminder that would deter him from returning to prison (Vasiljević, 2018: 206).

Prison tattoos inspired by Nazi iconography and emblems seem to be rather common among American inmates (McCarron, 2008: 96). Designed with the intention to shock and repel, these tattoos do not necessarily carry an anti-Semitic message, but are aimed to declare their owners' hate for African Americans as well as "white solidarity" and supremacy in general (McCarron, 2008: 96). Having in mind the fact that a large majority of inmates in American prisons have African American or Hispanic origins, it becomes clear that wearing such tattoos requires a considerable amount of courage on the behalf of their owners (McCarron, 2008: 96). This type of tattoos is typical for relativity novel "white prison subculture" in the USA, which pushed out previous ideologically ambiguous biker tattoos (Valentine 2000: 49). In European, and especially in Eastern European context Nazi inspired tattoos are a symptom of most extreme political groups, while function similar to American far right iconography is taken by nationalistic symbols.

Gang prison tattoos represent the signs of commitment to a small and very specific community (McCarron, 2008: 97). They are usually crude and contain very strong antisocial symbols focused on death and violence (skulls, snakes, the grim reaper and tombstones) (Byard, 2013: 536). The roots of gang tattoos can be found in the guild or craft tattoos, and their essential purpose is to emphasize incorporation and community (McCarron, 2008: 97-98). In most American prisons, the punishment for gang related tattooing is much more severe that for other cases of prison-made tattoos and if an inmate is discovered to be a member of a gang, he can be sent to solitary confinement even for an indefinite period of time (D’Amico, 2007: 2). Again, decentralised gangs such as "Bloods", "Crips" and various Latin American groups ("Sureños", "Norteños", "Nuestra Familia"...) represent a phenomenon which is almost unknown in the European context, including Serbia. The closest analogy in local context are tattoos with symbolism of sport club affiliated gangs.

Prison tattoos with religious or biblical implications (such as a cross, a quote or a portrait of a character from the Bible, a rosary, icons, sacral objects, etc.) are considered a response to prison atmosphere and its elements that trigger behaviour and personality changes, highlighting the need to interpret the meaning of life through religion (Perju-Dumbravă et al., 2016: 345). Religious prison tattoos are frequently inscribed on the bodies of prisoners with Hispanic origins (McCarron, 2008: 98).

Tattoos inspired by biblical motives seem to be very well tolerated by the inmates, as long as they are not combined or on the same part of the body (they 
usually occupy chest, back or arms) with other types of tattoos (Perju-Dumbravă et al., 2016: 345). From a psychological point of view, subsequent modifications of certain tattoos, particularly the replacement of vulgar tattoos with religious or biblically inspired ones, commonly indicates the change of prisoner's behaviour either caused by a change in his/her life or by him/her regretting the past crimes (Perju-Dumbravă et al., 2016: 345-348).

Photograph 2. Correctional Institution in Sremska Mitrovica, 2019.

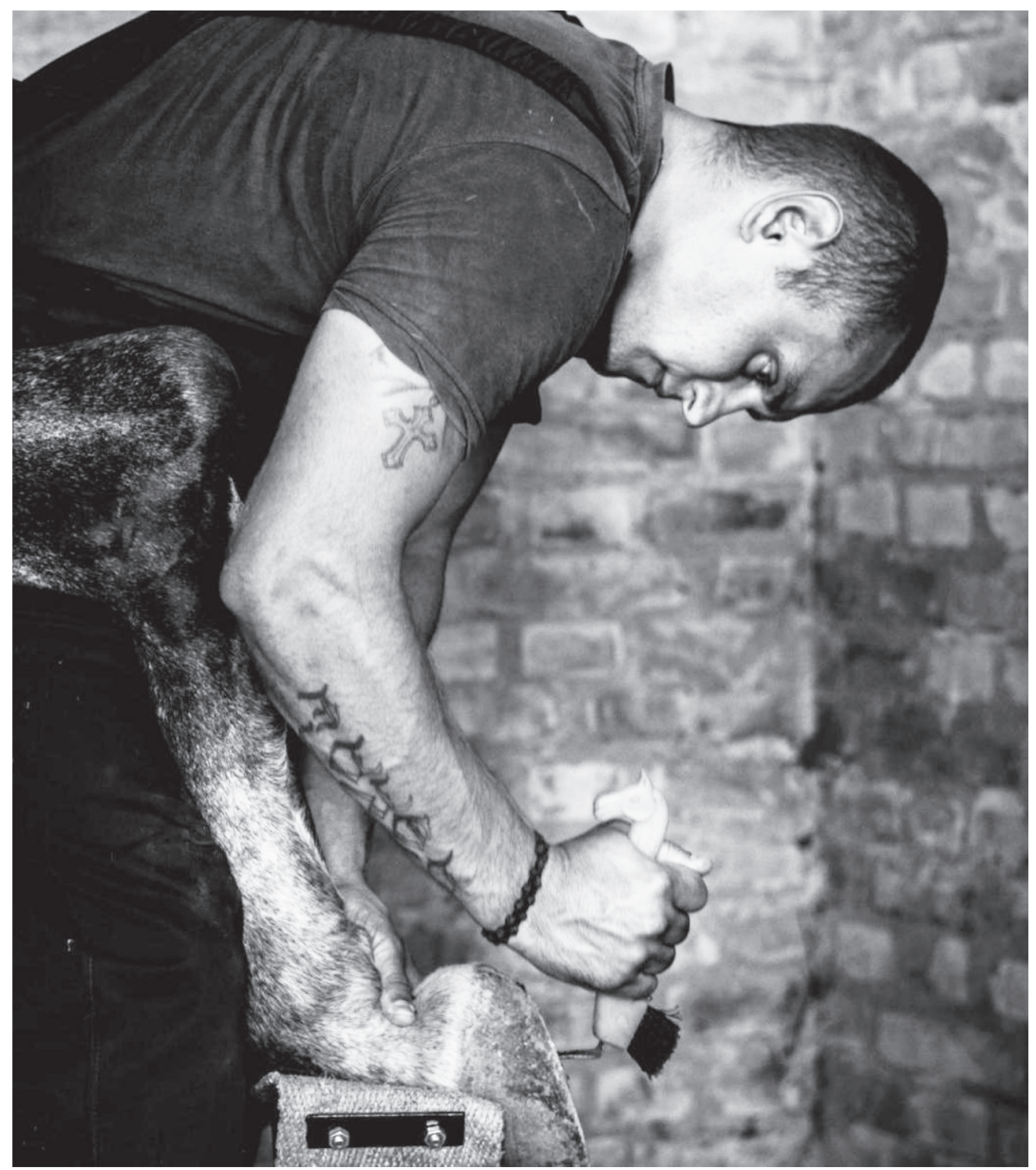

Author: Ana Batrićević

Memento mori prison tattoos are interpreted as a modern, secular replacement for conventional religious tattoos, especially in American prisons, where a skull, often accompanied by a bouquet of roses is a rather frequent motive (McCarron, 2008: 99). 
Photograph 3. Correctional Institution in Sremska Mitrovica, 2019.

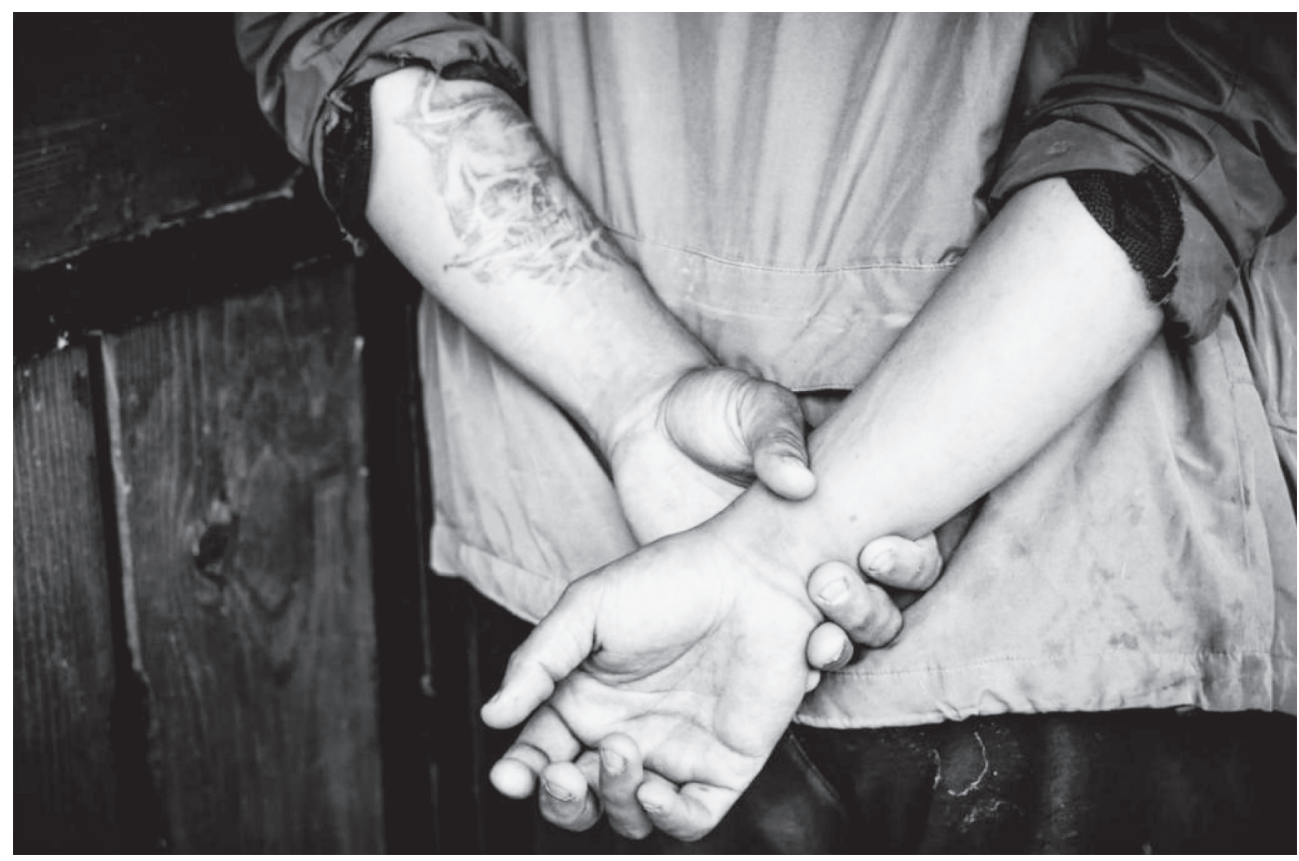

Author: Ana Batrićević

\section{Prison Tattoos as a Means of Countering prison deprivations}

According to Sykes, five fundamental deprivations, collectively known as the "pains of imprisonment", arise as the consequences of daily life in penitentiary institutions: 1) the loss of liberty, 2) the deficiency of desirable goods and services, 3 ) the absence of heterosexual relationships, 4) the missing of autonomy and 5) the lack of security (Ilijić, 2014 a: 140; Ilijić, 2014 b: 122-123). Long term exposure to prison deprivations is likely to cause serious mental health issues, during incarceration as well as after release, including: depression, hostility and increased risk of suicide (Edgemon, Clay-Warner, 2019) as well as some other problems such as: withdrawal, victimization among inmates and prison riots (Petrović, Jovanić, 2018: 479). Furthermore, in accordance with the so-called deprivation model, both material as well as symbolic frustrations emerging due to the prison environment may produce criminogenic effects by motivating the prisoners to develop their own informal "prison culture", as an opposite to official norms of conduct (Shammas, 2017), which can be interpreted as a specific kind of social game.

In fact, crime as a phenomenon cannot be completely understood without it's ludic component (Ignjatović, 2008: 143), and prison tattooing has a very interesting 
status form this perspective. Being at the same time a legal activity outside of prison, and an illegal one inside, tattooing offers a way for prisoners to feel the pleasure of playing with prison administration, and showing superiority over guards. Because of the complexity of the process which includes gathering of materials and hiding them, finding the artist, a place to make a tattoo and someone to keep watch, playing this social game requires a lot of planing. In that sense, it is not unlike other illegal prison activities, such as the misuse of drugs and alcohol and stashing weapons, cellphones and pornographic material. Analogy is very strong especially with use of drugs, both in technical and tactical aspects as well as in psychological rewards (Ivanović, 2011: 63-73). In that sense, prison tattooing is both an exercise and testing of guard's vigilance, as well as proving to oneself and others the rejection of prison norms and superiority over them. In the prison environment, where enforced rules are much tighter then under regular conditions, the breaches of rules can also bring great pleasure and excitement (Elias, Dunning, 1986: 65-66).

\section{The Prohibition of Tattooing inside Prisons}

In the majority of prisons worldwide, tattooing is considered an illegal activity (Hellard, Aitken, Hocking, 2007: 477). For example, most of correctional code of conduct manuals in American prisons formally treat tattooing as a "minor violation" of inmate disciplinary codes (D'Amico, 2007: 2). Also, According to Article 20 of Regulation on the House Rules of Penitentiaries and District Prisons (Official Gazette of the Republic of Serbia, No. 110/2014 and 79/2016), prisoners are allowed to keep the following things in their possession: personal hygiene items, shaving kit that does not endanger safety, orthopaedic devices, writing kit, tools for the cleaning of clothes and shoes, wrist watch, wedding or engagement ring, religious items and literature, bed sheets, underwear and shoes, pipe, tobacco and cigarettes and clothes and shoes for sports activities. Also, it is emphasized that prisoners can keep only the type and the number of things that would not allow them to breach order and safety inside the institution. So, although the House Rules do not explicitly mention tattooing, the list of acceptable and the characteristics of forbidden items clearly indicate that carrying out such an activity and keeping the items that are necessary for its conduct are prohibited.

One of key reasons why tattooing is forbidden in prisons is derived from the health risks that it is related to. The link between tattooing and the transmission of some infectious diseases has been familiar for a long time (Nishioka, Gyorkos, 2001: 27). Tattooing includes skin piercing and potential blood contact and, therefore represents a serious risk factor for the infection with blood borne 
viruses, particularly the HIV and hepatitis $\mathrm{C}$ and this risk becomes even greater if tattooing is done under prison conditions due to the lack of disinfection facilities and appropriate equipment (Hellard, Aitken, Hocking, 2007: 477). Since tattooing is illegal in prisons, prisoners have their tattoos made in an environment that has limited (if any) infection control precautions aimed at reducing the transmission of blood borne viruses (Hellard, Hocking, Crofts, 2004: 414).

\section{The Economy of Prison Tattoos}

Competencies in making tattoos and crafting needed tools and materials in prison have great value in clandestine prison economic transactions. First of all, it is one of the few prestigious artisan services that prisoners can provide to one another, and earn compensation in return. Secondly, since all materials needed for tattooing actually come from within the prison, investments in this kind of barter are minimal and include one's skill and the factor of risk taken. Last but not the least, because tattooing is an intimate and highly emotionally charged activity with permanent (and sometimes unwanted) consequences, prisoners who are getting the tattoo will try their best to please the artist without the use of coercion and to earn their trust. Paradoxically, tattooing as an illegal activity within the prison walls comes to resemble the most regular activities in the ordinary, everyday life ${ }^{1}$.

From an economic perspective, dichotomy of prison and non-prison tattoos applies to prison and non-prison tattoo artists. Later obviously have better position from the start, because they have mastered their competencies outside of prison and can use them immediately with good confidence. First category, which is apparently more interesting for the topic of this article, are the prisoners who decide to learn how to tattoo during their sentence, driven by artistic or financial motives. They typically start practising on their own bodies first, and after they have grasped the basics of tattooing, they start to tattoo other prisoners as well ${ }^{2}$.

\section{Mitigating the Negative Consequences of Prison Tattoos}

In spite of prohibitionist policies, prisoners continue tattooing themselves under unhygienic and risky circumstances (Awofeso, 2002:165). So, instead of

1 Hidden In America - Prison Ink, 04.04.2016, https://www.youtube.com/watch?v=aTdSd0VK0hE, accessed 16.11.2020.

2 Hidden In America - Prison Ink, 04.04.2016, https://www.youtube.com/watch?v=aTdSd0VK0hE, accessed 16.11.2020. 
arguing for its prohibition, there are some public health community's representatives advocating the legalisation of tattooing in prisons and suggesting that programmes should be developed that reduce prisoners' need and desire to have a tattoo in prison (Hellard, Hocking, Crofts, 2004: 414).

The idea to legalise tattooing in prisons and to allow the prisoners the access to professional tattoo artists is based upon the principle of harm minimisation (Awofeso, 2002: 165). Namely, tattooing in prisons is closely interrelated with other risky behaviours such as intravenous drug use and carries a serious risk of blood borne infections, such as hepatitis and HIV, due to the technique used, improvised equipment and non-compliance with infection control guidelines (Awofeso, 2002: 165). By allowing tattooing in prisons under proper conditions, these risks are expected to be minimised. Developing a program that would allow legalized tattooing in prisons is considered rather difficult and complex but it would significantly decrease the risk of infectious diseases transmission among prisoners (Hellard, Hocking, Crofts, 2004: 414). The example of the aforementioned approach can be found in the work of Canada Correctional Services that launched a Safer Tattooing Practices Initiative project in 2005, which was implemented through operational and educational component (Nafekh, 2009).

The operational component included the implementation of tattoo rooms in six federal institutions - one institution for men in each of the five regions (Atlantic, Cowansville, Bath, Rockwood and Matsqui Institutions) and one institution for women (Fraser Valley Institution for Women) (Nafekh, 2009). The educational component was delivered at Canada Correctional Service's five regional reception centres and it included the informing of all inmates with a new federal offence about the potential dangers of unsafe tattooing practices at the five regional reception centres (Nafekh, 2009). Moreover, the educational component provided information via guidelines document and pamphlets which were distributed at each of the six pilot sites (Nafekh, 2009). The Initiative increased the level of knowledge and awareness amongst staff and inmates about the prevention and control of blood borne infectious diseases transmission and indicated the potential of such program to reduce harm and exposure to health risk, to provide additional employment opportunities for inmates within the institution, and work skills applicable in the community (Nafekh, 2009).

Having in mind the connection between prison tattoos and criminal behaviour inside as well as outside prison, as well as their strong psychological, emotional and social symbolics, the question of their removal and its impact on offenders' future life inevitably arises. Since the removal of gang tattoos represents a statement about leaving gang life, it could be argued that the removal of prison tattoos could similarly be symbolize leaving a criminal lifestyle and becoming a 
productive member of the society (Rozycki Lozano et al., 2011). Namely, tattoos in general, and especially prison made ones that have an anti-social, criminal or gang membership symbolics, often represent a serious obstacle for the employment of former prisoners and deter them from obtaining regular source of income, which may lead to re-offending (Dooley, Seals, Skarbek, 2014: 269; Hardcastle et al., 2018: 51-54; Knežić, 2011: 78-79). Therefore, providing former prisoners with the opportunity to participate in free or low-cost tattoo removal programs could significantly increase the probability of their successful re-socialisation and social reintegration.

The work of a Northern California based non-profit organisation "Jails to Jobs" represents an example of good practice in this field, providing former and offenders that are about to be released from prison with advice and assistance related to employment. In that context, this organisation also keeps a searchable database of free and low-cost tattoo removal programs that are being applied across the USA, which includes more than 300 programs in 42 states. $^{3}$

\section{Conclusion}

The phenomenon of prison tattoos and tattooing in prison is intrinsically linked to the very nature of modern penitentiaries, sharing the same history with their institutional context. Alongside with the development of modern penal institutions, voluntary tattooing practices behind the prison walls have evolved into a complex system of symbols, roles, messages, relations and identities. On the one hand, in the era of visual media expansion, prison tattoos from certain areas (USA and Russia) have become a part of global culture, whereas on the other local variations, specific to some cultural contexts, are emerging as well. The latter have not been sufficiently scientifically examined yet, although the findings of such research could be of great significance.

There is no doubt that the everlasting appropriation of ones own artistic and emotional expression in a world substantially defined by deprivations has significant implications on prisoners' lives. That is the reason why the prisoners persistently keep making tattoos, despite the risks, obstacles and prohibitions, challenging the system and norms imposed upon them. Because of long duration of the entire process and its ever changing features, one question needs to be answered over and over again, and that is individual interpretation and understanding of this artistic practice through the eyes of its participants - prisoners

3 Jails to Jobs, What we do: Educate, inform, connect and assist, https://jailstojobs.org/what-we-do/, accessed 15.11.2020. 
themselves. This research endeavour could shed more light upon some still unknown aspects of prison culture and reveal complex social and emotional relations that stand behind the prison made tattoos.

\section{References}

- Awofeso, N. (2002) Jaggers in the pokey: understanding tattooing in prisons and reacting rationally to it, Australian Health Review, 25(2), pp.162-169.

- Byard, R. (2013) Tattoos: forensic considerations. Forensic Science, Medicine, and Pathology, 9(4), pp. 534-542.

- Caplan J 2000, 'Written on the body: the tattoo in European and American History', Reacktion Books, London.

- D'Amico, D. (2007) The Needle is Mightier than the Sword: Markets instead of Prohibition for Prison Tattoos, http://citeseerx.ist.psu.edu/viewdoc/downl oad?doi=10.1.1.517.8229\&rep=rep1\&type=pdf, accessed 13.11.2020.

- Perju-Dumbravă, D., Daniel, U., Gherman, C., Chiroban, O., Bonea, L.S., Radu C.C. (2016) Biblically Inspired Tattoos in Forensic Examinations Made on Inmates' Bodies in Prisons Territorially Assigned to the Forensic Institute of Medicine from Cluj. Journal for the Study of Religions and Ideologies, 15(45), pp. 338-356.

- Deter-Wolf, A., Robitaille, B., Krutak, L., Galliot, S. (2016) The World's Oldest Tattoos.

- Journal of Archaeological Science: Reports, 5, pp. 19-24. https://doi. org/10.1016/j.jasrep.2015.11.007

- Dey, A., Das, K. (2017) Why We Tattoo? Exploring the Motivation and Meaning. Anthropology, 5(1), https://doi:10.4172/2332-0915.1000174

- Dooley, B.D., Seals, A., Skarbek, D. (2014) The effect of prison gang membership on recidivism. Journal of Criminal Justice 42(3), pp. 267-275.

- Edgemon, T.G., Clay-Warner, J. (2019) Inmate Mental Health and the Pains of Imprisonment. Society and Mental Health, 9(1), pp. 33-50. https://doi. org/10.1177/2156869318785424

- Elias, N., Dunning, E. (1986) Quest for Excitement: Sport and Leisure in the Civilizing Process. Oxford: Blackwell.

- Goscilo H. (2012) Texting the Body: Soviet Criminal Tattoos. In: Goldfrank D. M. and Lysakov P. (Eds.). Cultural cabaret: Russian and American essays for Richard Stites. Washington, DC: New Academia Publishing, pp. 203-30.

- Hardcastle, L., Dowse, L., McGillivray, J., Newton, D., Rowe, S., Crosbie, J., Giles, M. (2018) A qualitative study on the experiences of ex-prisoners who are seeking employment, the experiences of practitioners who work with 
ex-prisoners who are seeking employment and the models of practice used. Sydney: UNSW Sydney. http://doi.org/10.26190/5b4fd5e63e8c6

- Hellard M.E., Aitken C.K.,Hocking J.S. (2007) Tattooing in prisons - not such a pretty picture. American Journal of Infection Control, 35(7), pp. 477-480.

- Hellard, M. E., Hocking, J. S., Crofts, N. (2004) The prevalence and the risk behaviours associated with the transmission of hepatitis $\mathrm{C}$ virus in Australian correctional facilities. Epidemiology and Infection, 132(3), pp. 409-415.

- Hidden In America - Prison Ink,04.04.2016, https://www.youtube.com/ watch? $\mathrm{v}=\mathrm{aTdSd} 0 \mathrm{VK} 0 \mathrm{hE}$, accessed 16.11.2020.

- Ignjatović, Đ. (2008) Kriminologija. Beograd: Pravni fakultet.

- Ilijić, Lj. (2014 a) Osuđeni i deprivacije: uticaj karakteristika ličnosti na intenzitet doživljavanja zatvorskih deprivacija. Beograd: Institut za kriminološka i sociološka istraživanja.

- Ilijić, Lj. (2014 b) Obrazovanje i profesionalno osposobljavanje osuđenih lica kao važan faktor redukcije recidivizma. Revija za kriminologiju i krivično pravo, 52 (1), str. 121-131.

- Ivanović, M. (2011) Narkomanija kao društvena igra. Beograd: Institut za kriminološka i sociološka istraživanja.

- Jails to Jobs, What we do: Educate, inform, connect and assist, https://jailstojobs. org/what-we-do/, accessed 15.11.2020.

- Jovanić, G., Petrović, V. (2018) Deprivacija slobode tokom izvršenja zatvorske kazne. Specijalna edukacija i rehabilitacija, 17(4), str. 477-500. https:// doi.org/10.5937/specedreh17-17878

- Knežić, B. (2011) Osuđenici i osoblje u zatvorima: zarobljeni zakonom i mogućnostima. Revija za kriminologiju i krivično pravo, 49 (1), str. 71-80.

- Lombroso, C. (1911 a) Criminal man, New York: G. P. Putnam's Sons.

- Lombroso, C. (1911 b) Crime, its Causes and Remedies. Boston: Little Brown and co.

- Radović, N., Đurđević, Z. (2017) (Ne)povezanost tetovaža sa kriminalom. Kultura polisa, 14(3), str. 193-202.

- McCarron, K. (2008) Skin and Self-Indictment: Prison Tattoos, Race, and Heroin Addiction. English Studies in Canada, 34(1), pp. 85-102.

- Nafekh, M (2009) Evaluation Report: Correctional Service Canada's Safer Tattooing Practices Pilot Initiative, https://www.csc-scc.gc.ca/text/pa/ev-tattooing-394-2-39/index-eng.shtml, accessed 15.11.2020.

- Nishioka S, Gyorkos TW. (2001) Tattoos as risk factors for transfusion-transmitted diseases. International Journal of Infectious Diseases, 5(1), pp. 27-34. https://doi.org/10.1016/s1201-9712(01)90045-1

- Omelchenko U.D., Karpenko A.A., Volkodav T.V. (2019) Tattoo or Taboo? The Social Stigma of Tattoos. Форум молодых ученых, 6(34), pp. 17-25. 
- Regulation on the House Rules of Penitentiaries and District. Prisons, Official Gazette of the Republic of Serbia, No. 110/2014 and 79/2016.

- Rozycki Lozano, A.T., Morgan, R. D., Murray, D.D., Varghese, F. (2011) Prison Tattoos as a Reflection of the Criminal Lifestyle. International Journal of Offender Therapy and Comparative Criminology 55(4), pp. 509-529.

- https://doi.org/10.1177/0306624X10370829

- Shammas, V.L. (2017) Pains of Imprisonment. In: K.R. Kerley (Ed.). The Encyclopedia of Corrections, https://doi.org/10.1002/9781118845387.wbeoc020

- Takač, Š., Pilija, V. (2012) Subkultura tetovaže sa aspekta identifikacije. Glasnik Antropološkog društva Srbije, 47, str. 249-259.

- Truhelka, Ć. (1986) Die Tätowirung bei den Katholiken Bosniens und der Hercegovina, in: Wissenschaftliche Mittheilungen Aus Bosnien und der Hercegovina, herausgegeben vom Bosnisch-Hercegovinischen Landesmuseum in Sarajevo, ed. Hoernes M., Band, V, Wien.

- Vasiljević, Đ. (2018) Dosije Atila. Beograd: Kontrast izdavaštvo.

- Valentine, B. (2000) Gangs and Their Tattoos: Identifying Gangbangers on the Street and in Prison. Boulder: Paladin Press.

- Wohlrab, S., Stahl, J., Kappeler P. M. (2007) Modifying the body: motivations for getting tattooed and pierced. Body Image, 4, pp. 87-95. 